\title{
Appraisal of the Perspective Level towards Occupational Hazards among Fixed Prothodontic Staff at Selected Dental Clinics, Saudi Arabia
}

\author{
Dr. Ibrahim Ayed Ali Almoshafi ${ }^{1}$, Dr. Saeed Mohammed S. Alqahtani ${ }^{2}$ \\ ${ }^{1}$ Dental Resident, Saudi Arabia \\ ${ }^{2}$ Dental Resident, Saudi Arabia
}

\begin{abstract}
Background: Oral release of compounds from biomaterials occurs, and adverse reactions may follow dental treatment. Especially in allergically vulnerable patients contact allergy may occur. There are reports from many different countries on contact allergy from gold/palladium alloys, components from polymer-based materials, chromium/cobalt alloys, and nickel. Notwithstanding, educational emphasis, the practical application of preparation design routinely exceeds the ideal taper and casts a different light on retention and resistance characteristics described in both laboratory and theoretical work. Objective: To Appraisal of the perspective level towards Occupational Hazards among Fixed prothodontic Staff at Selected Dental clinics, Saudi Arabia. Method: A crosssectional survey was conducted at five dental clinics, Saudi Arabia. 27 items self-administered questionnaire was provided to 200 fixed prothodontic staff in the research setting based on their area of their specialties to assess the level of awareness' towards occupational injury among fixed prothodontic staff at the selected dental clinics, Saudi Arabia. Results: This study finding showed that awareness towards Occupational Injury among some fixed prothodontic staff at dental clinics was variable. The majority (98.5\%) of the fixed prothodontic staff had a high level of prespective towards Occupational hazards in relation to Blood spills should be cleaned up promptly with sodium hypochlorite". On the other hand of the fixed prothodontic staff had a lowest level of awareness towards Occupational hazards in relation to Used needles can be recapped after giving an injection". Although, concerning the Intermittent Level of Awareness the lowest level was awareness towards Occupational Injury in relation to Blood spills should be cleaned up promptly with sodium hypochlorite" $(0.5 \%)$. While, regarding the highest Level of Awareness towards Occupational hazards was found in the item of "HCWs with non intact skin should not be involved in direct patient care until the condition resolves " (11.0\%). Conclusions: The current study results revealed that there were high levels of perspective among the fixed prothodontic staff towards occupational hazards within the study setting.
\end{abstract}

Keywords: Safety Measures; Occupational Hazards; \&Fixed prothodontic staff

\section{Introduction}

An ultimate dental adhesive should endow with a durable bond between dissimilar materials, possess constructive compressive and tensile strengths, have sufficient fracture toughness to prevent dislodgment as a result of interfacial or cohesive failures, be able to wet the tooth and the restoration, exhibit adequate film thickness and viscosity to ensure complete seating, be resistant to disintegration in the oral cavity, be tissue compatible, and demonstrate adequate working and setting times.

Consequently, there are five types of commercially available luting agents for the long-term cementation of fixed prostheses and they include: zinc phosphate, polycarboxylate, glass ionomer, resin composite, and resinmodified or "hybrid" glass ionomer cements. Each type is physically and chemically unique and no luting agent is ideal for all situations. The purpose of this article is to review the composition and characteristics of these luting agents. (Kuo .et al., 2006).

The ability to adhere to multiple substrates, high strength, insolubility in the oral environment, and shade-matching potential have made resin composite cements the adhesive of choice for esthetic type restorations, including resin composite inlays and onlays, allceramic inlays and onlays, veneers, crowns, FPDs, and the newly developed fiberreinforced composite restorations. Chemically polymerized resin composites are specifically recommended for luting base metal resin-bonded FPDs ("Maryland" type). Adhesion to noble metals can be achieved but requires tin-plating. Resin cements are useful when the preparation lacks optimal retention and resistance forms. Proper use requires multiple steps that are technique sensitive. (Odd Cathrine, et al., (2007).

According to Sorrs .et al., (2013), A knowledge of the complications that can occur with single crowns, fixed partial dentures, all-ceramic crowns, resin bonded prostheses, posts and cores, and implant prostheses enhances the scientific foundation upon which diagnosis and treatment planning are based and facilitates the communication of realistic expectations to patients. During a period of time when economic conditions make it difficult for patients to afford needed treatment, many patients' lives are changed through this worthy Foundation charitable grant program. Again, thank you for your generous support of the unique activities of the Osseo integration foundation.

Because of the extensive nature of the implant data base, the complications have been divided into 6 major categories (surgical, implant loss, bone loss, peri-implant soft tissue, mechanical, and phonetic/esthetic). When all types of restorations/prostheses are compared, implant prostheses

Volume 6 Issue 12, December 2017 


\section{International Journal of Science and Research (IJSR) \\ ISSN (Online): 2319-7064}

Index Copernicus Value (2016): 79.57 | Impact Factor (2015): 6.391

exhibited the highest incidence of complications. However, the incidence varies substantially with the type of implant prosthesis. The lowest incidence of complications occurred with implant single crowns, and implant over dentures had the highest incidence of complications.(Rapiti, et al., 2005).

Comparison of preparations done by residents and by prosthodontists in this study showed that ideal preparation taper is seldom achieved. The long-term clinical outcome of fixed prosthodontic treatment depends, in part, on the use of adhesives that can provide an impervious seal between the restoration and the tooth. There are several types of available luting agents, each possessing unique properties and handling characteristics. No one product is ideal for every type of restoration. To the greatest of our understanding, the attentiveness of fixed prothodontic staff in relation to knowledge and awareness about policies of safety measures within the work setting. Consequently, conducted this study to assess the level of awareness' towards occupational injury among fixed prothodontic staff at the dental clinics, Saudi Arabia.

\section{Participants and Methods}

This study was conducted in among fixed prothodontic staff at the dental clinics, Saudi Arabia. The study was granted ethical approval by the clinics ethical committee.

The participants were selected from the selected dental clinics. After signing an informed written consent form, the questionnaire was given to each participant. Before administration of the questionnaire, the purpose of the study was explained to each respondent and confidentiality of the information guaranteed.

The research was carried out by one of the authors who were appropriately trained in administering the informed consent and the self-report questionnaire to the participants. In this cross-sectional study, a structured questionnaire prepared by the authors, was administered to the participants.A32-item self-administered structured questionnaire about awareness' towards occupational injury among the selected fixed prothodontic staff, which advised de novo and tested. It included a full range of response options, designed to identify the practitioner's level of to assess their level awareness' towards occupational injury among fixed prothodontic staff within the selected setting. Prior to distribution of the questionnaire, a pilot study was done on a selective group of health care workers who were asked to fill out the questionnaire and return it back with their remarks and criticism. Minor changes were then made to the final tool.

The preliminary part of the questionnaire consisted of demographic information such as occupation, age, gender, and the marital status. The second part of the questionnaire comprised of questions regarding their level of awareness' towards occupational injury among medical staff. This part also assessed awareness' towards occupational injury. It took approximately 15 minutes to complete each appraisal.

The level of awareness' towards occupational injury among fixed prothodontic staff among fixed prothodontic staff at the dental clinics, Saudi Arabia. By examining questions. A score of " 1 " was assigned for a correct answer and " 0 " for an incorrect answer. A health care worker who obtained a total score of "5" was considered "very aware;" "4 or 3" "somewhat aware;" and "1 or 0" "not aware."The data were coded and analyzed by SPSS ${ }^{\circledR}$ for Windows ${ }^{\circledR}$ ver. 12.0. Strict confidentiality was maintained. All the data were stored in computers at a secured location, with access provided only to the researchers involved in the study. The $\chi 2$ test was used to test association between categorical variables. A p value $<0.05$ (two-tailed) was considered statistically significant differences.

\section{Results}

Level of Perspective' Towards Occupational Hazards among Fixed prothodontic staff at the selected clinics

\begin{tabular}{|c|c|c|c|c|c|c|}
\hline \multirow[t]{2}{*}{ Items of Occupational Hazards } & \multicolumn{2}{|c|}{$\begin{array}{c}\text { High Level } \\
\text { of Awareness }\end{array}$} & \multicolumn{2}{|c|}{$\begin{array}{l}\text { Intermittent Level } \\
\text { of Awareness }\end{array}$} & \multicolumn{2}{|c|}{$\begin{array}{l}\text { Low Level of } \\
\text { Awareness }\end{array}$} \\
\hline & No & $\%$ & No & $\%$ & No & $\%$ \\
\hline Universal precautions are applied to patients with HIV and viral hepatitis only" & 186 & $93.0 \%$ & 4 & $2.0 \%$ & 10 & $5.0 \%$ \\
\hline "Isolation is necessary for patients with blood-borne infections" & 179 & $89.5 \%$ & 10 & $5.0 \%$ & 11 & $5.0 \%$ \\
\hline Used needles can be recapped after giving an injection" & 164 & $82.0 \%$ & 16 & $8 \%$ & 20 & $10.0 \%$ \\
\hline $\begin{array}{l}\text { For decontamination of devices (with only contact with skin) washing with usual } \\
\text { detergent is enough" }\end{array}$ & 187 & $93.5 \%$ & 3 & $1.5 \%$ & 10 & $5.0 \%$ \\
\hline $\begin{array}{l}\text { Universal precautions are not necessary in situations that might lead to contact with } \\
\text { saliva" }\end{array}$ & 189 & $94.5 \%$ & 6 & $3.0 \%$ & 5 & $2.5 \%$ \\
\hline $\begin{array}{c}\text { "HCWs with non intact skin should not be involved in direct patient care until the } \\
\text { condition resolves " }\end{array}$ & 168 & $84.0 \%$ & 10 & $5.5 \%$ & 22 & $11.0 \%$ \\
\hline Blood spills should be cleaned up promptly with sodium hypochlorite" & 196 & $98.0 \%$ & 1 & $0.5 \%$ & 3 & $1.5 \%$ \\
\hline
\end{tabular}

This study finding showed that awareness towards Occupational Injury among some fixed prothodontic staff at dental clinics was variable. The majority $(98.5 \%)$ of the fixed prothodontic staff had a high level of prespective towards Occupational hazards in relation to Blood spills should be cleaned up promptly with sodium hypochlorite". On the other hand of the fixed prothodontic staff had a lowest level of awareness towards Occupational hazards in

\section{Volume 6 Issue 12, December 2017}




\section{International Journal of Science and Research (IJSR) \\ ISSN (Online): 2319-7064}

Index Copernicus Value (2016): 79.57 | Impact Factor (2015): 6.391

relation to Used needles can be recapped after giving an injection". Although, concerning the Intermittent Level of Awareness the lowest level was awareness towards Occupational Injury in relation to Blood spills should be cleaned up promptly with sodium hypochlorite" $(0.5 \%)$. While, regarding the highest Level of Awareness towards Occupational hazards was found in the item of "HCWs with non intact skin should not be involved in direct patient care until the condition resolves " (11.0\%).

\section{Discussion}

This study finding showed that awareness towards Occupational Injury among some fixed prothodontic staff at dental clinics was variable. The majority $(98.5 \%)$ of the fixed prothodontic staff had a high level of prespective towards Occupational hazards in relation to Blood spills should be cleaned up promptly with sodium hypochlorite". On the other hand of the fixed prothodontic staff had a lowest level of awareness towards Occupational hazards in relation to Used needles can be recapped after giving an injection". Although, concerning the Intermittent Level of Awareness the lowest level was awareness towards Occupational Injury in relation to Blood spills should be cleaned up promptly with sodium hypochlorite" (0.5\%). While, regarding the highest Level of Awareness towards Occupational hazards was found in the item of "HCWs with non intact skin should not be involved in direct patient care until the condition resolves " (11.0\%).

Another study reported by McCarthy,( 2000), involving 550 medical students and residents during the 1989-1990 training year likewise reported a high prevalence of needle stick injuries $(69 \%)$, and a higher frequency of injury (by a factor of 6) among surgical residents than among medical residents. In these two studies, rates of reporting needle stick injuries ranged from 13 to $23 \%$, and a more recent survey of all types of providers from an Iowa medical organization found that $34 \%$ had reported their exposure to an employee health service. On the other hand, the study carried by Regina (2002), showed that only $59 \%$ of surgical residents report such injuries extends previous observations that underreporting may result in a substantial underestimation of the magnitude of the problem.

The 'shortened dental arch' perception is a nominal treatment intervention approach that has been advocated for a wide range of partially edentulous patients. This concept favors imperfect prosthodontic intervention to achieve patient-perceived acceptable function levels in the presence of multiple missing teeth. The implementation of minimal interventions should be balanced by considering risk-tobenefit ratios, as well as the consequences of nonintervention or low-level prosthodontic interventions. The 'nonintervention' approach and low-level prosthodontic interventions have inherent consequences and welldocumented risks; professional ethics dictate that a practitioner present these risks as well as the known benefits of all treatment options. Developing countries are under significant pressure to effectively utilize limited resources, increase skilled human resources, provide advanced levels of care to very large numbers of patients and plan for the future dental health care of their society. Many developing countries are prime candidates for inadvertent abuse and misappropriation of prosthodontic materials, treatment modalities and human resources in trying to provide costeffective prosthodontic care. This research findings is congruent with the findings of the study carried out by (Rapiti, et al., 2005), who found that he greater awareness of universal precautions among health care workers employed for a longer period non-compliance among medical doctors and nurses are associated with insufficient knowledge, workload, forgetfulness, workplace safety and the insight that colleagues also failed to track.

Personnel protective equipments reduce the risk of exposure of the health care provider's skin or mucous membranes to potentially infectious materials. Protective barriers reduce the risk of exposure to blood and other body fluids to which universal precautions apply. Examples of protective barriers include gloves, gowns, masks, and protective eyewear. Just over one half of the respondents indicated that they were provided with protective equipment most times. Furthermore, more nurses were provided with protective equipment than medical technologists and medical doctors. Interestingly, more respondents who were aware of universal precautions reported being provided with protective equipment more often than those who were somewhat or not aware. This study results congruent with the research data carried out by Pournaras, et al,2004, who reported that less than two-thirds of health care workers claimed that they always used personal protective equipment such as aprons, gowns and gloves, during surgeries and while conducting deliveries. According to Jawaid, et al, among medical doctors working in a tertiary care hospital in Pakistan, compliance for hand washing was $86 \%$, for wearing gloves was $79 \%$, masks $46 \%$, eye goggles $25 \%$ and for using gowns/plastic aprons was $45 \% .35$ However, there is sometimes a high rate of non-compliance among health care workers and this may be due to a lack of understanding among health care workers of how to properly use protective barriers.

This study showed that there was high level of awareness' towards occupational injury among fixed prothodontic staff within the study setting. These findings suggest that training of dental staff to maintain and enhance their knowledge about occupational safety, blood borne pathogens and universal precautions could improve their use of universal precautions. Regular training should include the universal precautions, initial biohazard handling, safety policies, safety behavior, safety equipments, continuing monitoring and maintain continuous quality improvement concerning the practice of occupational safety.

\section{Acknowledgements}

Appreciation is hereby extended to all the participants and administrators staff at the selected dental clinics-Saudi Arabia. 


\section{International Journal of Science and Research (IJSR) \\ ISSN (Online): 2319-7064}

Index Copernicus Value (2016): 79.57 | Impact Factor (2015): 6.391

\section{References}

[1] Sorra , V, F.(2013).Safety culture assessment: a tool for improving patient safety in healthcare organizations. Westat, Research Blvd, Rockville, MD 20850, USA

[2] CDC: Universal Precautions for Prevention of Transmission of HIV and Other Blood borne Infections. Accessed 22 December 2008, [http://www.cdc.gov/]

[3] Rapiti Elisabetta, Prüss-Ustün, Hutin Yuvan: Assessing the burden of disease from sharps injuries to healthcare workers at national and local levels. 2005, Geneva: World Health Organization, Environmental Burden of Disease Series, No 11

[4] Odd Cathrine, Abed Abdullah, Strathdee Steffanie, Scott Paul, Botros Boulos, Safi Naquibullah, et al: HIV, hepatitis $\mathrm{C}$, and hepatitis $\mathrm{B}$ infections and associated risk behavior in injection drug users, Kabul, Afghanistan. Emerging Infectious Diseases Journal. 2007, 13: 1327-31.

[5] Kuo Irene, ul-Hasan Salman, Galai Noya, Thomas David, Zafar Tariq, Ahmed Mohaamad, Strathdee Steffanie: High HCV seroprevalance and HIV drug use risk behaviours among injection drug users in Pakistan. Harm Reduction Journal. 2006, 3: 26-10.1186/14777517-3-26.

[6] Saif-u-Rehman , Rasoul Mohammad, Wodak Allex, Claeson Mariam, Friedman Jed, Sayed Ghulam: Responding to HIV in Afghanistan. Lancet. 2007, 370: 2167-9. 10.1016/S0140-6736(07)61911-4.

[7] Guo YL, Shiao J, Chuang Y-C: Needlestick and sharps injuries among health-care workers in Taiwan. Epidemiology and Infection Journal. 2003, 122: 259-65. 10.1017/S0950268899002186.

[8] Regina Chan, Molassiotis Alexander, Eunica Chan, Virene Chan, Becky Ho, Chit-Ying Lai, et al: Nurses' knowledge of and compliance with universal precautions in an acute care hospital. International Journal of Nursing Studies. 2002, 39: 57-63.

[9] Pournaras S, Tsakris A, Mandraveli K, Faitatzidou A, Douboyas J, Tourkantonis A: Reported needlestick and sharps injuries among healthcare workers in a Greek general hospital. Occupational Medicine. 2004, 7: 4236. 10.1093/occmed/49.7.423.

[10] Lacerda RA. Infeccao hospitalar e sua relacao com a evolucao das practicas de assistencia a saude. In: Lacerda RA, ed. Controle de infeccao em centro cirurgico. Sao Paulo: Atheneu, 2003: 9-23.

[11] Lacerda RA, Egry EY. As infeccoes hospitalares e a sua relacao com o desenvolvimento da assistencia hospitalar: reflexoes para analise praticas atuais de controle. Rev Latinoam Enfermagem 1997;5:13-23.

[12] Beltrami EM, Williams IT, Shapiro CN, Chamberland ME. Risk and management of blood-borne infections in health care workers. Clin Microbiol Rev 2000;13(3):385-407.

[13] Gerberding JL. Incidence and prevalence of human immunodeficiency virus, hepatitis B virus, hepatitis C virus, and cytomegalovirus among health care personnel at risk for blood exposure: final report from a longitudinal study. J Infect Dis 1994;170(6):1410-7.
[14] Ruben FL, Norden CW, Rockwell K, Hruska E. Epidemiology of accidental needle-puncture wounds in hospital workers. Am J Med Sci 1983;286(1):26-30.

[15] Pruss-Ustun A, Rapiti E, Hutin Y. Estimation of the global burden of disease attributable to contaminated sharps injuries among health-care workers. Am J Ind Med 2005;48(6):482-90.

[16] Khuri-Bulos NA, Toukan A, Mahafzah A, et al. Epidemiology of needlestick and sharp injuries at a university hospital in a developing country: a

[17] year prospective study at the Jordan University Hospital, 1993 through 1995. Am J Infect Control 1997;25(4):322-9.

[18] Wang FD, Chen YY, Liu CY. Analysis of sharpedged medical-object injuries at a medical center in Taiwan. Infect Control Hosp Epidemiol 2000;21(10):656-8.

[19] Pruss-Ustun A, Rapiti E, Hutin Y. Sharp injuries: global burden of disease from sharp injuries to health care workers Geneva, Switzerland. World Health Organization, 2003.

[20] Orji EO, Fasubaa OB, Onwudiegwu U, et al. Occupational health hazards among health care workers in an obstetrics and gynaecology unit of a Nigerian teaching hospital. J Obstet Gynaecol 2002;22(1):75-8.

[21] Recommendations for protection against viral hepatitis. MMWR Morb Mortal Wkly Rep 1985;34(22):313-24, 329-35.

[22] Recommendations for preventing transmission of infection with human T-lymphotropic virus type III/lymphadenopathy-associated virus in the workplace. MMWR Morb Mortal Wkly Rep 1985;34(45):681-6, 691-5.

[23] McCarthy GM. Universal Precautions J Can Dent Assoc 2000;66:556-7.

[24] Update: human immunodeficiency virus infections in health-care workers exposed to blood of infected patients. MMWR Morb Mortal Wkly Rep 1987;36(19):285-9.

[25] Acquired immunodeficiency syndrome (AIDS): precautions for health-care workers and allied professionals. MMWR Morb Mortal Wkly Rep 1983;32(34):450-1.

[26] Garner JS. Hospital Infection Control Practices Advisory Committee. Guideline for isolation precautions in hospitals. Infect Hosp Epidemiol 1996; 17:53-80.

[27] Spire B, Barre-Sinoussi F, Montagnier L, Chermann JC. Inactivation of lymphadenopathy associated virus by chemical disinfectants. Lancet 1984;2(8408):899901.

[28] Martin LS, McDougal JS, Loskoski SL. Disinfection and inactivation of the human $\mathrm{T}$ lymphotropic virus type III/Lymphadenopathy-associated virus. J Infect Dis 1985;152(2):400-3.

[29] McDougal JS, Martin LS, Cort SP, Mozen M, Heldebrant CM, Evatt BL. Thermal inactivation of the acquired immunodeficiency syndrome virus, human $\mathrm{T}$ lymphotropic virus-III/lymphadenopathy-associated virus, with special reference to antihemophilic factor. J Clin Invest 1985;76(2):875-7.

[30] Olowu O, Oluaje E, Kehinde O. Knowledge and practice of universal precautions among final year

\section{Volume 6 Issue 12, December 2017}




\section{International Journal of Science and Research (IJSR) \\ ISSN (Online): 2319-7064}

Index Copernicus Value (2016): 79.57 | Impact Factor (2015): 6.391

medical and dental students in the University College of Ibadan. Dokita 2001;28:6-9.

[31] Odujurin OM, Adegoke OA. AIDS: Awareness and blood handling practices of health care workers in Lagos. Nig J Epidl 1995;11(4):425-30.

[32] Palenick C. Strategic planning for infection control. J Canadian Dental Association 2000;66:556-7.

[33] Danchaivijitr S, Tantiwatanapaiboon Y, Chokloikaew $\mathrm{S}$, et al. Universal precautions: knowledge, compliance and attitudes of doctors and nurses in Thailand. $\mathrm{J}$ Med Assoc Thai 1995;78 Suppl 2:S112S117.

[34] Twitchell K. Bloodborne pathogens: what you need to know-Part I. Journal of the American Association of Occupational Health Nurses 2003;51:46-7.

[35] Godin G, Naccache H, Morel S, Ebacher MF. Determinants of nurses' adherence to universal precautions for venipunctures. Am J Infect Control 2000;28(5):359-64.

[36] Stein AD, Makarawo TP, Ahmad MFR. A survey of doctors' and nurses' knowledge, attitudes and compliance with infection control guidelines in Birmingham teaching hospitals. Journal of Infection Control 2003;54:68-73.

[37] Trim JC, Adams D, Elliott TS. Healthcare workers' knowledge of inoculation injuries and glove use. $\mathrm{Br} \mathbf{J}$ Nurs 2003;12(4):215-21.

[38] Rana JS, Khan AR, Haleem AA, et al. Hepatitis C: knowledge, attitudes and practices among orthopedic trainee surgeons in Pakistan. Ann Saudi Med 2000;20(5-6):477-9.

[39] Wang H, Fennie K, He G, et al. A training programme for prevention of occupational exposure to bloodborne pathogens: impact on knowledge, behaviour and incidence of needle stick injuries among student nurses in Changsha, People's Republic of China. J Adv Nurs 2003;41(2):187-94.

[40] Heinrich J. Occupational Safety: Selected cost and benefit implications of needle stick prevention devices for hospitals (letter to House of Representatives from US General Accounting Office), 2000.

[41] Gerberding JL. Clinical practice. Occupational exposure to HIV in health care settings. N Engl J Med 2003;348(9):826-

[42] Connington A. Has the point been made? a needlestick injury awareness survey. Safe Gard Medical 2002.

[43] Alam M. Knowledge, attitude and practices among health care workers on needle-stick injuries. Ann Saudi Med 2002;22(5-6):396-9.

[44] Sadoh WE, Fawole AO, Sadoh AE, et al. Practice of universal precautions among healthcare workers. J Natl Med Assoc 2006;98(5):722-6.

[45] Jawaid M, Iqbal M, Shahbaz S. Compliance with standard precautions: a long way ahead. Journal of Public Health 2009;38:85-8.

[46] Evanoff B, Kim L, Mutha S, et al. Compliance with universal precautions among emergency department personnel caring for trauma patients. Ann Emerg Med 1999;33(2):160-5.

[47] Gershon RR, Karkashian CD, Grosch JW, et al. Hospital safety climate and its relationship with safe work practices and workplace exposure incidents. Am J Infect Control 2000;28(3):211-21.
[48] Janjua NZ, Razaq M, Chandir S, et al. Poor knowledge-predictor of nonadherence to universal precautions for blood borne pathogens at first level care facilities in Pakistan. BMC Infect Dis 2007;7:81.

[49] Cutter J, Jordan S. Uptake of guidelines to avoid and report exposure to blood and body fluids. J Adv Nurs 2004;46(4):441-52.

[50] Nelsing S, Nielsen TL, Nielsen JO. Noncompliance with universal precautions and the associated risk of mucocutaneous blood exposure among Danish physicians. Infect Control Hosp Epidemiol 1997;18(10):692-8.

[51] Brooks AJ, Phipson M, Potgieter A, et al. Education of the trauma team: video evaluation of the compliance with universal barrier precautions in resuscitation. Eur $\mathbf{J}$ Surg 1999;165(12):1125-8.

[52]Richman G, Dorsey A, Stayer S, Schwartz R. Compliance With Standard Precautions Among Pediatric Anesthesia Providers. The Internet Journal of Anesthesiology 2000 4(4):1-8.

Volume 6 Issue 12, December 2017

www.ijsr.net

Licensed Under Creative Commons Attribution CC BY 